\title{
W S C Copeman: his importance in contemporary medicine
}

\author{
A E Porritt, F Dudley Hart
}

'When the Royal College of Physicians of London appointed their first special committee to survey the rheumatic diseases in 1933 this field of medicine was derelict. Since that time academic interest in all branches of rheumatology has gradually become world wide and is rapidly increasing'. So wrote Dr W S C Copeman in the preface to the third edition of his Textbook of the Rheumatic Diseases in 1964 . 'He did not point out that this transformation had come about as a result, to a remarkable degree, of his own efforts, and of his clear sighted determination to establish rheumatology as a scientific medical discipline'. So wrote Dr J T Scott in 1971 in page one of the Annals of 1971 soon after Will Copeman died.

It is now 21 years since Will Copeman died. There are not many men in this country, apart from a few pioneer workers who made outstanding contributions to the study of arthritic disorders, who contributed as much as did Will Copeman to the contemporary medical scene. Rheumatology was a neglected subject-the Cinderella of medical specialties, as the late Lord Horder wrote many years ago, in Great Britain and in most other countries before the 1939-45 war. The particular study of diseases of the musculoskeletal locomotor system, rheumatology, was not recognised as a specialty in its own right, as was the study of diseases of other systems. Little research was being done in the rheumatic disorders in the early 1930 s and very little money was devoted to such research despite the fact that these disorders are among the most common afflicting mankind, causing more suffering than do most and over far longer periods, to say nothing of the social problems and economic loss involved. This great gap in the country's defences against ill health was not peculiar to the United Kingdom, and it is only in certain and relatively few medically and scientifically advanced countries that a proper scientific study of the rheumatic disorders and what can be done for the sufferers from them has been given the same sort of priority as other specialties. The rheumatic and arthritic disorders did not then appear to be as dangerous as malignant or cardiac disease, and arthritic patients had learnt how to struggle on with their painful affliction the hard way, as for most of them there was little or no alternative, beds being few in hospitals and priorities being given to more urgent potentially fatal or more readily treatable conditions. The spa hospitals were, however, treating many patients in those prewar and pre-National Health Service days in Bath, Droitwich, Harrogate, and elsewhere. So home remedies, much folklore, simple home applied physical measures, and simple analgesics (such as aspirin) and other supportive treatment from their general practitioners were all that most patients received before the 1930s. The departments of physical medicine throughout the land gave what service they could but rarely had they many, or indeed any, beds for inpatient treatment and their work covered all physical therapy and rehabilitation for patients in all other specialties, surgical as well as medical. The rheumatic diseases were taken for granted by the whole community. In such a field unorthodox forms of therapy flourished for any treatment and any attention is welcome when one is experiencing what has aptly been called 'the long pain', and the patient and his or her relatives will grasp at straws and try any treatment, however apparently absurd, in their desperate efforts to help control the disorder or alleviate the suffering it causes. It is to the immense credit of Will Copeman that he saw the scene clearly in those early years and what could be done about it.

Any doctor, nurse, or social worker who has had anything to do with patients with severe arthritis cannot but feel deep sympathy for them, and also feel the need to help them as much as possible. Will Copeman differed from other doctors, however, in that he went several stages further. He not only saw the need for action but actually did something about it. $\mathrm{He}$ appreciated the fact that the study of the rheumatic diseases, rheumatology, was not then an accepted specialty. Too little was known of the subject and far too little research was being undertaken in studying, sorting out, classifying, and trying to find the causes of the many varieties of rheumatic disorder. Few first line doctors and research workers were interested. Rheumatology had first to be made respectable so that more doctors and research workers would take it up. The subject was inadequately represented in the medical curricula of most of the medical schools in the United Kingdom and students at qualification had received in most universities relatively little education in the subject. Rheumatology and its importance in the home, in society, and in industry had not been adequately emphasised. Will started his own individual rheumatic units at the West London Hospital in Hammersmith and at the Hospital of St John and St Elizabeth in St 
John's Wood, London. In each case he had been appointed as paediatrician, but his interests in rheumatic fever and arthritis in childhood soon spread to adults and before long these two units were operating fully with interested junior trainees and research workers taking active part. At this time, apart from excellent work being done in rheumatic disorders in a number of departments of physical medicine, only a few other rheumatic units in London, such as that of Dr Francis Bach and Dr Philip Ellman at St Stephen's Hospital, Fulham, the Charterhouse Clinic, and the British Red Cross Centre in Peto Place, where Will also worked, were actively functioning. During the second world war he had met Dr Oswald Savage in the Persian Gulf and they became firm friends and worked together closely after the war for some 20 years in the rheumatic field.

In this last centre in Peto Place on the 3 March 1936 six doctors met under the chairmanship of Dr Matthew Ray to form the first British clinical group to study rheumatic disorders, and this was known as the Committee for the Study and Investigation of Rheumatism. In the following year membership was thrown open to all medical men interested and working in rheumatology to a maximum number of 100 and the name was changed at the original suggestion of Dr Ray to the Heberden Society after the great eighteenth century doctor of that name. The first clinical and research society into the study of the rheumatic diseases in this country was therefore initiated, but it was Will Copeman, a founder member, and later president, who injected much new blood and great enthusiasm into it, encouraging and introducing many new members already working and interested in the subject. He was at pains to make the subject a right and proper one for teaching hospitals and others to take up as a specialty and to start rheumatological units with beds available for patients as well as to provide full outpatient facilities under consulting doctors on the staff of such hospitals. It was his enthusiasm and campaigning spirit that made rheumatology respectable and got it off the ground and into the air. The Heberden Society rapidly became world famous and the meeting place for all interested medical and scientific workers in the field of rheumatology in the United Kingdom. In 1949-50 Will Copeman became president and the society never looked back. It became affiliated to the British League against Rheumatism and later, together with the British Association of Rheumatology and Rehabilitation, became transformed into the British Society for Rheumatology. Will also not only started the Heberden library, which is now situated in the Royal College of Physicians in Regent's Park, London, but also gave many books to it and drew up the first three catalogues in 1954, 1960, and 1966. Through the British League members of the society also became members of the European and International League Against Rheumatism. Will Copeman, therefore, not only advanced the study of, and research into, the rheumatic disorders in this country but helped enrich and spread the study elsewhere in Europe and throughout the world.
No man in this country contributed more to the national and international scene than did Will Copeman through these organisations. He had done this in his own particular way, by a mixture of personal charm and persuasion, getting all sorts of people active and interested in the subject. But his flair for organisation, his inspired knack of getting the roots right, so that the tree would flourish in the right ground, watered correctly by the right finances, and growth encouraged by the right gardeners, were his and his alone. The Heberden Society in those early days had many famous members: Lord Horder, Lord Cohen of Birkenhead, and Sir Ronald Tunbridge, for example, who gave much to the society in different ways, but without Will Copeman its growth and development just would not have happened. He had the greatest of great arts at his fingertips, the art of getting things off the ground.

The Empire Rheumatism Council was founded in 1936 as a voluntary organisation to finance research into arthritis and all rheumatic diseases. H R H the Duke of Gloucester was patron, Lord Horder its first president, and Sir William Willcox its first chairman. Mr Victor Howell became the first general secretary. Will was particularly keen on the 'Empire' factor and the existence today of strong and active associations in Australia, New Zealand, and Canada bears ample witness to this interest. From modest beginnings and entirely from voluntary sources with no state aid Will Copeman built this organisation up until it is today the major research organisation devoted to the rheumatic disorders in this country, and one of the major research organisations in Europe. It was this organisation which initiated and originally financed the professorial chairs in rheumatology in this country, the first two being in Manchester (Professor J H Kellgren) and the Royal Postgraduate School of London (Professor E G L Bywaters), for Will Copeman saw clearly that a proper study of the subject should come through the university teaching centres of the country and that it should have proper and full academic and scientific status. Only through the universities could students' education in the rheumatic disorders be improved and proper emphasis on research into, and study of, these diseases be initiated and encouraged.

It seemed to several people that an academic research centre devoted entirely to study and research into the rheumatic disorders would be a good thing, a kind of National Rheumatism Research Centre, similar to the Judd Street Ophthalmological Centre, which, in relation to Moorfields Eye Hospital, had done such valuable work in the study of diseases of the eye. Will Copeman met Professor Norman Ashton of the Ophthalmological Institute, who had done such excellent research work there and who had seen the centre grow and flourish from its beginning. Will considered a similar research centre in rheumatology would be an excellent idea and this started a chain of events which later, owing to the stimulus provided by Dr Lancaster and the great generosity of $\mathrm{Mr}$ Terence and $\mathrm{Mrs}$ Mathilda Kennedy, led to the Kennedy Institute being built at Hammersmith. It is now, and has 
been for many years, an active and fully functioning centre for research into the rheumatic disorders, and a fitting and appropriate memorial to those whose energies, foresight, and financial assistance put it there. It is sad that two of those responsible for its creation, Mrs Mathilda Kennedy and Dr Lancaster, did not live to see its opening, but it stands now as their memorial. Will Copeman saw it come into being and lived to see it through its early teething troubles. It is also his memorial in many ways.

In addition to these activities Will Copeman had his hospital work and a busy Harley Street practice. He was consultant rheumatologist to the army and to the Star and Garter home for ex-servicemen in Richmond. He was a justice of the peace in London, an enthusiastic founder member of the faculty of the history of medicine in the Society of Apothecaries, of which he was at one time master. He was an active fellow of the Royal Society of Medicine, was president of the Hunterian Society and the Hunterian orator of 1948 and was president of the epidemiological and historical sections and vice president of the section of medicine of the Royal Society of Medicine. He was closely associated with the foundation of the Annals of the Rheumatic Diseases in 1939 and he watched its development thereafter as a member of the editorial board and from 1954 to 1970 as editor with personal pride, care, and affection. His Textbook of the Rheumatic Diseases, first published in 1948, is still the main British textbook on the subject, the present editor being Dr J T Scott. Yet despite all these activities he was essentially a home loving man with his wife, Helen, and family around him. He loved the company of his fellow men and was a regular attender at his club, the Athenaeum, and lunched there frequently, but his first love was his own family circle. He was very proud of being the son of a famous father, Dr Sydney Arthur Monckton Copeman, FRS, and of his two daughters, son and sons-in-law, who continue to help in the affairs and activities of the Arthritis and Rheumatism Council in many ways. To some people he seemed a rather cold austere figure, dignified and aristocratic and somewhat withdrawn from the common man. This was an entirely false impression. As an ex-ensign of the Coldstream Guards in the first world war he held himself like a guardsman and being tall looked over the heads of most of his contemporaries. But he was essentially a warm hearted and generous man and excellent company at a medical meeting, a conference overseas, at an evening at the Royal College of Physicians, or any other social occasion. He had a keen sense of humour, and was, for a great man, particularly dependent on his friends and colleagues and sensitive to their feelings. It was this dependence on you, his friend, that endeared you to him. He was, in the nicest and most meaningful sense of the word, a cultured person and his knowledge of things aesthetic and artistic was extraordinarily comprehensive. He was seldom entirely sure he was in the right, would ask others for their honest opinion and, moreover, and this is very rare in one's friends, usually acted on it. In exchange he was well informed on a large number of things, loved good food and wine, and was a perfect host. He himself always ate sparingly and preserved his slim athletic figure to the end. After an evening in his company one left with intellectual and psychological batteries charged, with new ideas to think over, new plans to work on, and with new and often unexpected horizons to view. Few people at their departure have left such a gap in the lives of their family and their friends, and few people have made such an impact on the contemporary medical scene.

In collaboration with Colin G Barnes, E G L Bywaters, D L Gardner, J H Glyn, J H Kellgren, G D Kersley, O Savage, J T Scott, D Woolf. 